\title{
Comprehensive assessment brings out shortcomings in almost every school building
}

\author{
Tero Marttila ${ }^{1,}$, Jukka Lahdensivu ${ }^{1}$, and Juha Pekkanen ${ }^{2}$ \\ ${ }^{1}$ Tampere University, Faculty of Build Environment, 33014 Tampereen yliopisto, Finland \\ ${ }^{2}$ Finnish Institute for Health and Welfare, Department of Health Security, Environmental Health, 70701 Kuopio, Finland
}

\begin{abstract}
Consideration of the big picture is needed when evaluating aspects of the building with relevance for reporting of poor indoor air quality or symptoms. Even the most accurate longitudinal measurements do not remove the need for expertise and broad understanding of the different possible sources and causes of indoor air exposures. Finnish Institute for Health and Welfare (THL), in collaboration with Tampere University (TAU), studies the association between school buildings of Helsinki and pupil reported health symptoms. The present paper focuses on introducing the methods and classifications as well as presenting the results about the condition of the buildings. Characteristics of 53 school buildings have been assessed by visiting the buildings and by going through the previous building investigation reports. Visits relied mainly on visual inspections with an extensive checklist and some none intrusive momentary measurements about the dampness, pressure difference, and indoor air quality (IAQ). The major strength of the study is that all the possible school buildings in certain areas were inspected and assessed using the same methods, irrespective if the building had a long history of indoor air problems or not. That makes it possible to evaluate the general prevalence of the problems in school buildings, which has been highlighted as an open question by the National Indoor Air and Health Program 2018-2028, coordinated by THL. The first results indicate that every school building has its shortcomings. However, none of the studied buildings was in a very bad condition either. The results indicate that it is not possible to draw a clear line between the buildings with 'good' or 'poor' IAQ.
\end{abstract}

\section{Introduction}

Many school buildings in Finland are in need for renovation. Korhonen et al. (2018) estimated that it would take 1.8 billion euros to renovate all educational buildings of Finnish municipalities into a good condition [1]. That means that educational buildings constitute approximately $20 \%$ of the total estimate of 9 billion euros need for renovation in the municipal building stock of Finland [1]. To meet modern-day standards in all renovated buildings, we would have to invest even more: the amount of need for refurbishment is estimated to be 16.5 billion euros in the whole municipal building stock and 2.75 billion euros in educational buildings [1]. These are inaccurate estimations of costs, but the numbers clearly indicate that we cannot let the need for renovation to grow in the same way as has been done during the last decades. [1]

We assume that the buildings are healthier for the users if we invest in renovating the buildings. Unfortunately, sometimes a renovation fails, and some people may also have lost their confidence in the quality and success of the renovating in general [2]. One aim of this paper is to study the impact of the level of renovation on the condition of building and on the estimated exposures.
In order to help to estimate the indoor air risks, Finnish Institute of Occupational Health (TTL) has developed a method to classify buildings to four categories of indoor air (IA) exposure [3]. The foundation of that classification is to detect possible hidden mould damage and other sources of impurities. Pressure differences must be considered to estimate the significance of the infiltration from the damage in the structures. In other words, the assessment of the probability of abnormal IA exposure means evaluating the risk for undesired circumstances of building-related exposure to mould and other hazards for health. Tähtinen et al. (2018) did not find statistical associations between the four-level categorisation of the probability of abnormal IA exposure and the employees' perceived symptoms, health information, and perceived psychosocial work environment. [3, 4]

As part of the present study, Savelieva et al. (2019) found associations between IEQ problems in 129 schools in Helsinki and increased reporting of especially respiratory and general symptoms. The experts of the city of Helsinki evaluated IEQ problems, but no standardized inspections of the buildings were done. Their evaluation of moisture damage correlated moderately with the assessment of the moisture damage in the present study. [5]

\footnotetext{
* Corresponding author: tero.marttila@tuni.fi
} 
The present study introduces a new method of comprehensive inspection for evaluating the IEQ. Later, the data will be associated with reported health symptoms. This paper presents and classifies the building data, describes research methods and publishes the first results about the condition of the buildings in the data.

\section{Research data and methods}

\subsection{Research data}

Final research data consisted of 53 school buildings in the city of Helsinki, Finland. All school buildings of two school districts, along with all Swedish-speaking schools in Helsinki, $(n=70)$ were originally intended to be included in the study, but 17 buildings had to be excluded due to various reasons. We had to exclude six buildings because of on-going major overhaul or otherwise limited access. Five branch schools, in which less than 20 pupils had responded to the symptom questionnaire, were excluded, as they cannot be used in the future papers. However, the final research data of the present paper does include six side buildings of the inspected schools with a less than 20 questionnaire responses. One excluded school operated in six buildings, but the symptom data couldn't be separated between those buildings, so all six buildings were excluded from inspection. Probably some of those buildings would have been excluded due to low number of respondents as well. Finally, we were able to include $76 \%$ of the intended 70 school buildings in the study.

The total amount of inspected buildings of Finnishspeaking schools in the data was 37 and the amount of inspected buildings of Swedish-speaking schools was 16 . The majority of the buildings in the study operated for primary school grades, but five buildings operated only for secondary school grades, and seven buildings for both degrees of comprehensive school.

Temporary buildings of four schools were also inspected in the same manner as the actual buildings, but the structures and method of construction of those barrack buildings cannot be compared with proper buildings. Also, the construction years of temporary buildings are unknown. Therefore those buildings were not included in the data, but some general findings of the temporary buildings are included in Chapter 3 .

Construction years of the studied buildings are presented in Figure 1, which also shows three substantial gaps in the age span of the buildings in the sample. The first and longest gap is 26 years between 1923 and 1949 . Despite the length of the gap, this is not a major disadvantage of the sample, because there was no substantial development in the structures of the school buildings during these years. The lack of buildings from the beginning of the 1940's is probably due to World War II.

The second gap in the sample is not really a gap, but it is a considerable shortage of data from the late 70's to the late 80 's. Only two buildings are in this category. Central Statistical Office of Finland (StatFin 2018) shows a similar shortage in the school building production in whole Helsinki during the periods of the first two gaps. The third gap and shortcoming of the sample is that the modern buildings in the study are mainly from the beginning of the 21 st century. All the buildings in the study are more than five years old.

The time since the last renovation and the level of the renovation, of course, affect the condition of the building. Therefore the data is classified in Table 1 not only by the method of construction of certain eras but by the level of the renovation too. Buildings in each cell are similar together.

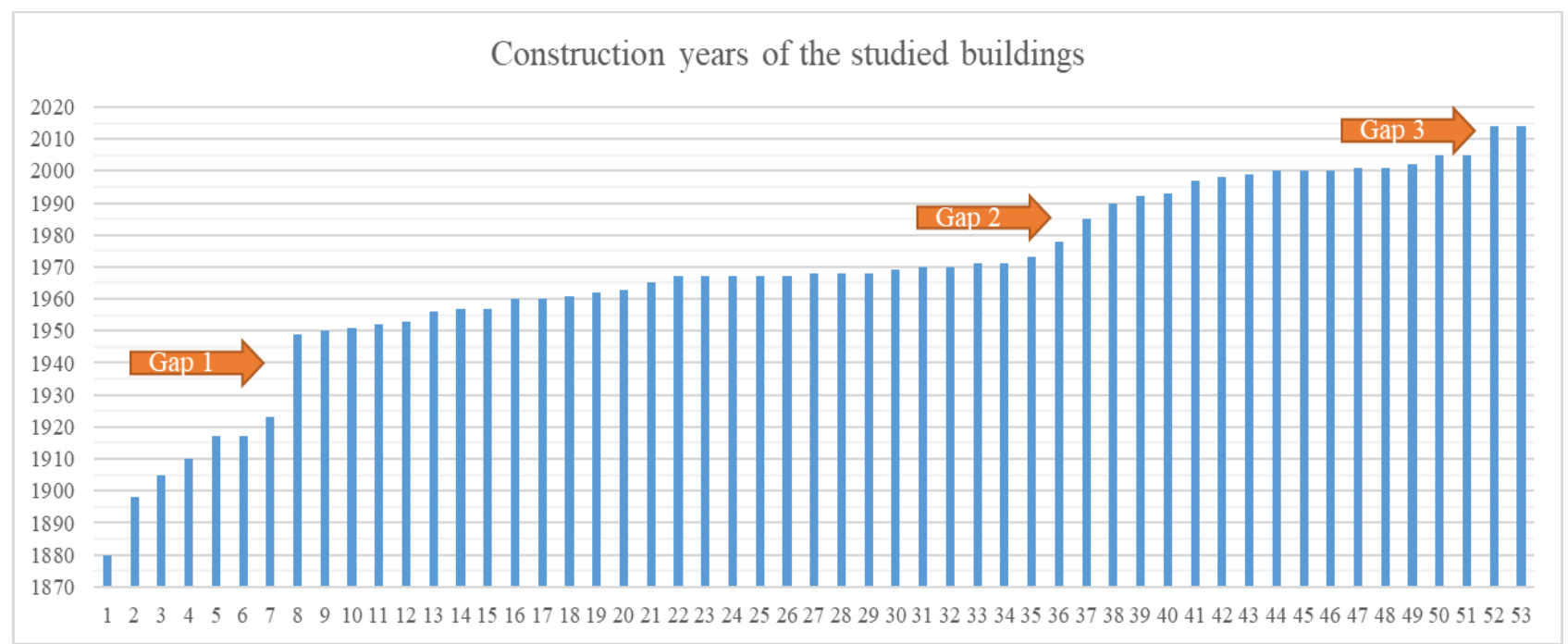

Fig. 1. Distribution of the construction years of the buildings in the study $(n=53)$. Oldest is from 1880 and the newest are from 2014. 
Table 1. Classification of the building data $(n=53)$.

\begin{tabular}{|c|c|c|c|c|}
\hline $\begin{array}{r}\text { Level of } \\
\text { maintenance } \\
\text { and renovation }\end{array}$ & \begin{tabular}{ll}
\multicolumn{2}{|l}{ Only basic maintenance } \\
$\checkmark$ & urgent repairs \\
$\checkmark$ & windows, roof and \\
& some surface materials \\
& renewed if necessary
\end{tabular} & 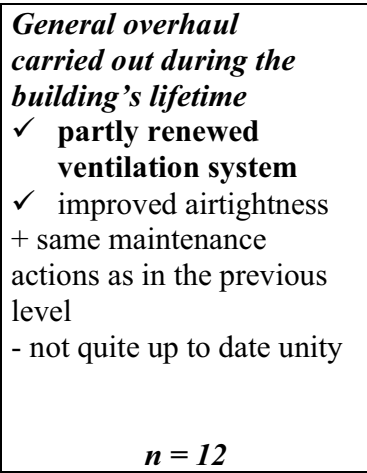 & $\begin{array}{l}\text { Major overhaul } \\
\text { carried out during the } \\
\text { building's lifetime } \\
\checkmark \quad \text { new balanced } \\
\text { ventilation, equivalent } \\
\text { in the whole building, } \\
\text { but not necessarily up } \\
\text { to date } \\
\text { + same maintenance and } \\
\text { renovation actions as in the } \\
\text { previous level } \\
\quad n=12\end{array}$ & \begin{tabular}{|ll} 
Heavy major overhaul \\
carried out during the last \\
ten years \\
$\checkmark \quad$ completely new \\
balanced ventilation \\
in the whole building \\
$\checkmark$ & significantly improved \\
& airtightness \\
$\checkmark$ & roof and most indoor \\
& surfaces renewed \\
$\checkmark$ & windows and facade \\
& renewed if necessary \\
& $n=10$
\end{tabular} \\
\hline $\begin{array}{c}\text { before } 1924^{*} \\
\quad n=7\end{array}$ & $\begin{array}{cl}\checkmark & \text { natural ventilation } \\
\checkmark & \text { maintained with } \\
& \text { respect to the original } \\
& \\
& \boldsymbol{n}=\boldsymbol{0} \\
\end{array}$ & \begin{tabular}{|ll}
$\checkmark$ & $\begin{array}{l}\text { somewhat improved } \\
\text { airtightness }\end{array}$ \\
$\checkmark$ & maintained with respect \\
& to the original \\
& $\quad \boldsymbol{n}=\mathbf{3}$
\end{tabular} & $\begin{array}{cl}\checkmark & \text { improved airtightness } \\
\checkmark & \text { renovated in respect to } \\
& \text { the original } \\
& n=4 \\
& n=4\end{array}$ & $n=0$ \\
\hline $\begin{array}{c}1949-1962 * \\
n=11\end{array}$ & & $n=4$ & $n=4$ & 3 \\
\hline $\begin{array}{c}1963-1980 \\
n=14\end{array}$ & $n=0$ &  & & $\begin{array}{c}n=7 \\
\text { (of which } n=3 \text { very heavy } \\
\text { major overhaul with } \\
\text { renewed façade) }\end{array}$ \\
\hline $\begin{array}{l}1981-2000^{* *} \\
\quad n=7\end{array}$ & $\begin{array}{l}\checkmark \text { relatively up to date } \\
\text { ventilation } \\
\qquad n=5 \\
\end{array}$ & 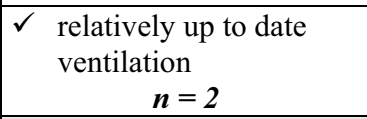 & & \\
\hline $\begin{array}{l}1998-2014 * * * \\
\quad n=9\end{array}$ & $\begin{array}{c}\checkmark \begin{array}{l}\text { original up to date } \\
\text { ventilation } \\
n=9\end{array} \\
\qquad\end{array}$ & $n=0$ & & \\
\hline $\begin{array}{c}\text { side buildings } \\
\quad n=5\end{array}$ & \multicolumn{4}{|c|}{$\begin{array}{l}\checkmark \text { Five side buildings in this data are not used and maintained in the same manner as the primary buildings of the } \\
\text { schools and are therefore analyzed separately (years of construction 1951,1967, 1968,1968 and 2000) }\end{array}$} \\
\hline
\end{tabular}

*No buildings in this data from between 1924 and 1948.

**Two buildings from the year 2000 in the data are allocated to this category because the structures of those are closer to the method of construction in the 1990's. On the other hand, also due to the type of building and structures, one building from 1998 is allocated in the category of more modern buildings.

***Most of the buildings in this category of modern buildings are from the beginning of the century. All the buildings in the data are more than five years old.

The type of ventilation is a dominant attribute in the classification of the data. Every building in the data has at least partly mechanical ventilation in some classrooms or the staff's room. Few buildings also include classrooms with natural ventilation, and some buildings' mechanical ventilation system is for an exhaust only. Those buildings are more than 70 years old and have, of course, went through at least one general overhaul during the lifespan of the building. Major overhaul in this study means that the building has a balanced ventilation system. However, it might not meet all the standards of modern-day, which is a bottom-line criterion to be listed as a heavy major overhaul in this study. Three buildings in the data have recently gone through very heavy major overhauls with a complete renovation of all the surfaces and non-bearing structures of the building.

Side buildings have conventional structures, and the years of construction are known, but in this study, five of those buildings are not used and maintained in the same manner as the primary buildings, and therefore those buildings were included in a separate category.

\subsection{Research methods and variables of the study}

The condition of the buildings is evaluated in the quantitative dataset with 17 variables. Values in the dataset are based on documents of previous investigations and a walk through inspection with a checklist and simple momentary measurements. Every buildings' investigation reports and other inspection documents about indoor air quality and structural conditions after 2002 are stored in a real estate information system of the city of Helsinki. We had access to all the relevant documents, and they were reviewed to evaluate the condition of the buildings for the current study.

Walkthrough inspection of one building took approximately 3 hours with a very detailed checklist of more than 100 variables. It evaluated not only the significance and impact of every observation but also the extent and target area of the observation. Momentary measurements included measurements of temperature, pressure differences over the exterior wall and between 
rooms, as well as $\mathrm{CO} 2$ in some cases. Longitudinal measurements had been part of many previous investigations, but in some cases, it is not clear if the situation (especially outside the operating hours) had been improved or not.

To be able to use all of the detailed information in statistical analyses, variables with simple, but rough scales were created. Many photos were taken during the inspections, and those have been very useful together with the checklists and previous documents for assessing the values for the variables. These variables will then be used in the later study to examine a possible association between the building condition and reported health symptoms.

Variables of the current study are the following:

- v1 moisture damage

- v2 air leak from moisture damage or other sources of impurity (from structures of the building)

- v3 significant under pressure over exterior walls

- v4 emissions (usually VOC -volatile organic

compounds) from flooring

- v5 man-made vitreous fibres (MMVF) in indoor air

- v6 other sources of impurities

- v7 problems with the ventilation system

- v8 indoor temperature too high or too low

- v9 stuffiness

- v10 smell of mould

- v11 other smell

- v12 structural moisture risks

- v13 other moisture risks

- v14 weighted summary score of v1-v13

- v15 assessment of abnormal indoor air (IA) exposure circumstances

- v16 inspector's subjective evaluation of the potential for building-related symptoms

- v17 overall exposure score

Rating scales for the variables v1, v2, v15 and v16 are presented in Table 2. Variables v3-13 were rated on the scale $0=$ "no", 1 = "possible", 2 = "yes". Middle value 1 can also mean lesser problem, perception or exposure. Rough scale made it possible to give a value to each variable for every building, meaning that the data does not include any missing inputs. That was essential for building a summary score (v14). Variable v17, as explained later, is constructed from variables v15 and v16 and has a scale from 1 to 20 .

As presented, every variable is coded so that the lowest value (usually zero) means no exposure and the highest value represents the highest exposure. Also this is necessary for building a summary score. Many problems, like moisture damage and VOC's, may be reflected in several variables. This is, however, not the case for MMVF. Therefore the significance of MMVF is emphasized in the weighted summary score (v14) by giving to MMVF a weight of 2, while all the other variables were not weighted. The significance of moisture is emphasized as a mutual factor behind many variables. Some variables show also a moderate correlation together when tested with Kendall rank correlation (Kendall's tau), as presented in Chapter 3.
Table 2. Rating scales for the variables v1, v2, v15 and v16.

\begin{tabular}{|c|c|c|c|c|}
\hline & $\begin{array}{l}\boldsymbol{v 1} \\
\text { moisture } \\
\text { damage }\end{array}$ & $\begin{array}{l}\mathbf{v 2} \\
\text { air leak }\end{array}$ & $\begin{array}{l}\text { v15 } \\
\text { exposure } \\
\text { assessment }\end{array}$ & \multirow{2}{*}{$\begin{array}{l}\text { v16 subjective } \\
\text { evaluation for } \\
\text { building-related } \\
\text { symptoms } \\
\text { scale 1-10 }\end{array}$} \\
\hline $\mathbf{0}$ & $\begin{array}{l}\text { no } \\
\text { damage }\end{array}$ & $\begin{array}{l}\text { no } \\
\text { confirmed } \\
\text { air leaks }\end{array}$ & $\begin{array}{l}\text { no } \\
\text { exposure }\end{array}$ & \\
\hline 1 & $\begin{array}{l}\text { local } \\
\text { damage }\end{array}$ & $\begin{array}{l}\text { some } \\
\text { individual } \\
\text { air leaks }\end{array}$ & $\begin{array}{l}\text { unlikely } \\
\text { exposure }\end{array}$ & 1-2 very unlikely \\
\hline 2 & $\begin{array}{l}\text { extent } \\
\text { damage }\end{array}$ & $\begin{array}{l}\text { regular air } \\
\text { leaks }\end{array}$ & $\begin{array}{l}\text { possible } \\
\text { exposure }\end{array}$ & 3-4 unlikely \\
\hline 3 & $\begin{array}{l}\text { many } \\
\text { extent } \\
\text { damage }\end{array}$ & $\begin{array}{l}\text { regular air } \\
\text { leaks and } \\
\text { high under } \\
\text { pressure }\end{array}$ & $\begin{array}{l}\text { moderate } \\
\text { exposure }\end{array}$ & 5-6 possible \\
\hline 4 & & & $\begin{array}{l}\text { significant } \\
\text { exposure }\end{array}$ & 7-8 likely \\
\hline 5 & & & $\begin{array}{l}\text { very } \\
\text { significant } \\
\text { exposure }\end{array}$ & 9-10 very likely \\
\hline
\end{tabular}

Results for comparison of the buildings in the current study, however, are based on separate overview variables, which were evaluated independently. Weighted summary score (v14) was built mainly for possible use in the later study and also to test the reliability of independent overall exposure score v17, which is constructed from variables v15 and v16. Reason for the independent overview variables v15 and v16 is that the variables v3-v14 do not take into account the scale and the extent of the problems. Overview variables evaluate the big picture of the condition of the building and the risk for unsatisfactory indoor air quality and perceived health symptoms.

Assessment of indoor air exposure circumstances (v15) is based on TTL's four-level classification [3], which was described briefly in Chapter 1. Ratings 0, 2 and 4 in the current study represent grades 1, 2 and 3 of TTL classification. Middle steps between the first three values of TTL classification were added due to rough scale and difficulties of allocating and separating buildings without proper condition investigations. Some buildings had also many more previous investigations than others. Even with the middle steps, the majority of the buildings fell in two middle categories of the scale. Therefore, the subjective evaluation for building-related symptoms (v16) was introduced. The scale is from 1 to 10 , and the main purpose for the variable is to classify the buildings of different conditions to different categories, while the conservative variable v15 fails to do this due to rough scale and insufficient information (i.e. lack of investigations). The strength of the v15 is the support by proved information, and therefore it is multiplied with 2 to achieve the same weight (scale of 0 10) for summing it with v16 for the final overall exposure score v17. The scale for v17 sums up from 1 to 20 , where the higher score estimates a higher risk for perceived health symptoms related to building and indoor environment. The distribution of the overall scores is illustrated in Figure 2.

Despite the independent evaluation of the overview values, it should be noted that the v15 is mainly based on 
the same information as variables v1-5, but considers the target area better. As for v16, it takes into account also elements of the rest of the variables and also rises the overall exposure score of the new buildings, which had not been properly investigated. Despite the subjective nature of the variables v15-v17, all are based on both inspection and previous documents.

Inaccuracy and weaknesses of subjective assessments are discussed in Chapter 4, but already before moving to results, it is necessary to mention that even though the type of evaluation is not very exact and measured, it allows the comparison of a large number of unique buildings comprehensively without extremely heavy, precise and difficult design of study. Data, schedule, and aims of the study dictated the research methods.

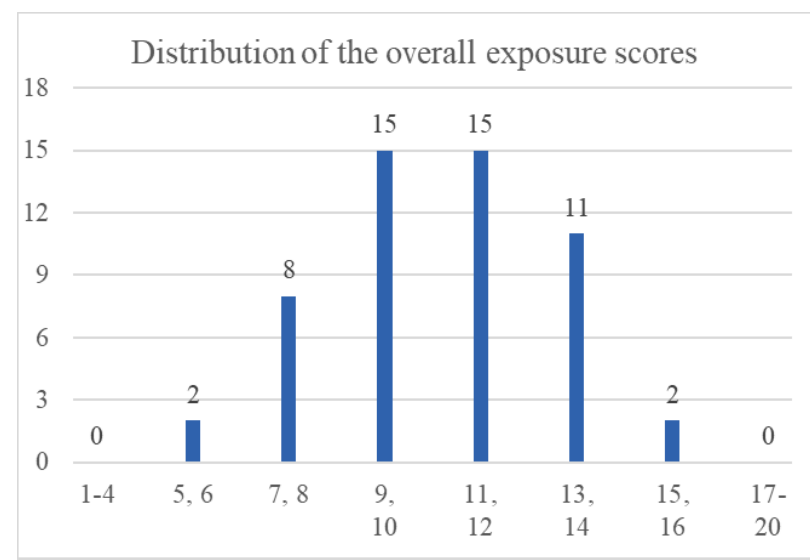

Fig. 2. Number of the overall exposure scores of the buildings distributed to eight categories $(n=53)$.

\section{Results}

Results for the variables v1, v2, v15 and v16 are presented in Table 3. Local moisture damage was observed in the majority of the buildings. This type of damage can be outside the building or old damage, and it may or may not have an influence on indoor air. Only one building was rated as 3 for $\mathrm{v} 1$ and one for $\mathrm{v} 2$. Including class 2, extent damage was observed in 16 buildings and regular air leaks in 20 buildings.

Results show that almost every building had leaks. In this data, only three buildings were rated as no confirmed air leaks, and in fact, some amount of infiltration air through the structures is very likely on those too. It should be noted that extent damage is often in a location without likely connection to the indoor air (IA) of a classroom or other room of the main usage. Therefore only four building were rated as significant exposure in the assessment of abnormal IA exposure circumstances v15.

In this study, the school buildings of Finnishspeaking schools had a better average of 10,4 for overall exposure score, while the average for buildings of Swedish-speaking schools was 11,1. The five side buildings in this data were generally in a rather bad condition.

Results of the temporary barrack buildings were not included in the main analyses of the present study, but those buildings were actually quite good when evaluated with the same overview variables as the proper buildings in this study. General findings are that these barrack buildings often suffered from unsatisfactory temperature conditions and noise or draft from the ventilation as well as other ventilation problems.

Too high indoor temperature is quite common but usually a local problem in many schools. Often it associates with stuffiness, even though this study did not find a statistical correlation between the two.

Table 3. Results for the variables v1, v2, v15 and v16. The first column presents the scale. Bolded numbers present the number of observations for each criterion of comparison.

\begin{tabular}{|c|c|c|c|c|}
\hline & $\begin{array}{l}\boldsymbol{v 1} \\
\text { moisture } \\
\text { damage }\end{array}$ & $\begin{array}{l}\text { v2 } \\
\text { air leak }\end{array}$ & $\begin{array}{l}v 15 \\
\text { exposure } \\
\text { assessment }\end{array}$ & \multirow{2}{*}{$\begin{array}{l}\text { v16 subjective } \\
\text { evaluation for } \\
\text { building-related } \\
\text { symptoms }\end{array}$} \\
\hline 0 & $\begin{array}{l}\text { no } \\
\text { damage: } \\
\mathbf{6}\end{array}$ & $\begin{array}{l}\text { no } \\
\text { air leaks: } \\
\mathbf{3}\end{array}$ & $\begin{array}{l}\text { no: } \\
\mathbf{0}\end{array}$ & \\
\hline 1 & $\begin{array}{l}\text { local } \\
\text { damage: } \\
\mathbf{3 1}\end{array}$ & $\begin{array}{l}\text { individual } \\
\text { air leaks: } \\
\mathbf{3 0}\end{array}$ & $\begin{array}{l}\text { unlikely: } \\
4\end{array}$ & $\begin{array}{l}\text { 1-2; } \\
\text { very unlikely: } \\
\mathbf{0}\end{array}$ \\
\hline 2 & $\begin{array}{l}\text { extent } \\
\text { damage: } \\
\mathbf{1 5}\end{array}$ & $\begin{array}{l}\text { regular air } \\
\text { leaks: } \\
\mathbf{1 9}\end{array}$ & $\begin{array}{l}\text { possible: } \\
\mathbf{2 3}\end{array}$ & $\begin{array}{l}\text { 3-4; } \\
\text { unlikely: } \\
\mathbf{1 1}\end{array}$ \\
\hline 3 & $\begin{array}{l}\text { several } \\
\text { extent } \\
\text { damage: } \\
\mathbf{1}\end{array}$ & $\begin{array}{l}\text { air leaks } \\
\text { and high } \\
\text { under } \\
\text { pressure: } \mathbf{1}\end{array}$ & moderate: & $\begin{array}{l}5-6 ; \\
\text { possible: } \\
\mathbf{2 6}\end{array}$ \\
\hline 4 & & & $\begin{array}{l}\text { significant: } \\
\mathbf{4}\end{array}$ & $\begin{array}{l}\text { 7-8; likely: } \\
\mathbf{1 6}\end{array}$ \\
\hline 5 & & & $\begin{array}{l}\text { very } \\
\text { significant: } \\
\mathbf{0}\end{array}$ & $\begin{array}{l}\text { 9-10; } \\
\text { very likely: } \\
\mathbf{0}\end{array}$ \\
\hline
\end{tabular}

Results for the variables v3-v13 are presented in Table 4. Results with a decent amount of findings in all categories are illustrated with bolded numbers. Unfortunately, some of the results were split mainly into two categories only. Weakest distributions, only one dominant class, are for the variables v4 floor emissions and v10 smell of mould.

Polyvinyl chloride (PVC) or linoleum flooring is at least partly used in almost every building, and emissions from the floors (v4) are therefore evaluated possible in all but one building. However, VOC measurements weren't common in the buildings, and only two buildings were graded as 'yes' for the measured VOC emissions from the floors. Due to its distribution, the variable v4 is not useful for the later analyses. 
Table 4. Results for the variables v3-v14 $(n=53)$.

\begin{tabular}{|c|c|c|c|c|}
\hline $\begin{array}{l}\text { scale for } \\
\text { variables }\end{array}$ & $0=$ no & $\begin{array}{c}1= \\
\text { possible }\end{array}$ & $2=$ yes & $\begin{array}{l}\text { kedall's } \\
\text { tau with } \\
\text { the year of } \\
\text { construct. }\end{array}$ \\
\hline $\begin{array}{l}\mathrm{v} 3 \text { under } \\
\text { pressure }\end{array}$ & 15 & 27 & 11 & $0.24 *$ \\
\hline $\begin{array}{l}\text { v4 floor } \\
\text { emissions }\end{array}$ & 1 & 50 & 2 & -0.01 \\
\hline v5 MMVF & 17 & 30 & 6 & 0.01 \\
\hline $\begin{array}{l}\text { v6 other } \\
\text { impurities }\end{array}$ & 7 & 27 & 19 & -0.02 \\
\hline $\begin{array}{l}\text { v7 ventilation } \\
\text { problems }\end{array}$ & 5 & 34 & 14 & 0.07 \\
\hline $\begin{array}{l}\text { v8 indoor } \\
\text { temperature } \\
\text { unsatisfactory }\end{array}$ & 21 & 22 & 10 & -0.09 \\
\hline v9 stuffiness & 30 & 20 & 3 & -0.16 \\
\hline $\begin{array}{l}\text { v10 smell of } \\
\text { mould }\end{array}$ & 49 & 4 & 0 & $-0.26^{*}$ \\
\hline $\begin{array}{l}\text { v11 other } \\
\text { smell }\end{array}$ & 27 & 12 & 14 & $-0.20^{\prime}$ \\
\hline $\begin{array}{l}\text { v12 structural } \\
\text { moisture risks }\end{array}$ & 1 & 33 & 19 & -0.06 \\
\hline $\begin{array}{c}\mathrm{v} 13 \text { other } \\
\text { moisture risks }\end{array}$ & 0 & 24 & 29 & $0.21^{\prime}$ \\
\hline $\begin{array}{l}\text { v14 weighted } \\
\text { sum. score }\end{array}$ & $\begin{array}{c}0-12: \\
20\end{array}$ & $\begin{array}{c}13-18: \\
28\end{array}$ & $\begin{array}{c}19-30: \\
\mathbf{5}\end{array}$ & -0.15 \\
\hline
\end{tabular}

Kendall rank correlation between selected variables are presented in Table 5. Variables with weak distribution i.e., results mainly in one or two categories, are left out from Table 5, but Table 4 shows the correlations of each variable with the year of construction. Negative correlations suggest the higher exposure for the older buildings, but none of the variables show a strong correlation with the year of construction.

Pressure differences are best studied with longitudinal measurements, which had been carried out and documented in some previous investigation reports of various buildings in the data. However, also momentary measurements can prove significant problems, which are rated as 'yes' for the variable v3. Lesser or local under pressure or uncertain observation, for example, due to wind or temperature conditions, are rated as 'possible'. Buildings with less than $5 \mathrm{~Pa}$ under pressure and no reason to suspect significant problems outside the operating hours or in other than measured locations of the buildings, were rated as 'no under pressure'.

Under pressure is common in new tight buildings as the positive value of kendall rank correlation with the year of construction also suggests in Table 4. Evaluation of moisture damage and air leaks are dominant factors for the assessment of IA exposure circumstances, and new buildings are not even investigated so well that those would have scored high exposure for v15 in this study. That explains the missing correlation between variables v3 and v15 even though the under pressure is considered for v15. Old buildings with mechanical extraction ventilation would score high for both v3 and $\mathrm{v} 15$, but that type of buildings was not common in the studied data.

Undesired pressure differences were also graded as ventilation problems, and therefore the variables v3 and v7 correlate together. Other examples of the problems with the ventilation system are insufficient air-rate or inhibited flow, dirty inlet or outlet, insufficient or faulty system. Previously documented or measured findings were usually rated as 'yes' and visual observations as 'possible'.

In this study, variable v6 'other sources of impurities' seems to act a little like overview variables and has a moderate correlation with many other variables. This might be connected to a known fact that buildings with poor IEQ are often multi-problematic, and already the general feeling and cleanliness are weak in those buildings.

Table 6 presents the v17 averages for the older buildings of the data in the previously introduced groups of classification.

Table 5. Kendall rank correlation for selected variables $(n=53)$

\begin{tabular}{|c|c|c|c|c|c|c|c|c|c|c|c|c|}
\hline & $\begin{array}{l}\begin{array}{l}\text { year of } \\
\text { building }\end{array} \\
\end{array}$ & v1 & v2 & v3 & v5 & v6 & v7 & v8 & v11 & v14 & v15 & v16 \\
\hline v1 & $-0.22 *$ & 1 & & & & & & & & & & \\
\hline v2 & -0.09 & 0.10 & 1 & & & & & & & & & \\
\hline v3 & $0.24 *$ & 0.10 & 0.00 & 1 & & & & & & & & \\
\hline v5 & 0.01 & 0.20 & 0.20 & 0.06 & 1 & & & & & & & \\
\hline v6 & -0.02 & 0.14 & $0.22^{\prime}$ & 0.08 & $0.36^{* *}$ & 1 & & & & & & \\
\hline v7 & 0.07 & -0.02 & 0.21 & $0.47 * * *$ & 0.15 & $0.31 *$ & 1 & & & & & \\
\hline v8 & -0.09 & 0.00 & 0.21 & 0.01 & 0.18 & 0.19 & 0.06 & 1 & & & & \\
\hline v11 & $-0.20^{\prime}$ & -0.06 & 0.15 & -0.05 & -0.00 & $0.33 * *$ & 0.15 & 0.07 & 1 & & & \\
\hline v15 & -0.18 & $0.32 *$ & $0.33 *$ & 0.08 & $0.29 *$ & $0.36 * *$ & $0.31 *$ & $0.32 * *$ & $0.28 *$ & $0.52 * * *$ & 1 & \\
\hline v16 & -0.12 & $0.23^{\prime}$ & 0.16 & 0.21 & $0.26^{*}$ & $0.40 * *$ & $0.32 * *$ & $0.28 *$ & $0.35^{* *}$ & $0.60 * * *$ & $0.35 * *$ & 1 \\
\hline v17 & -0.15 & $0.30 * *$ & $0.27 *$ & 0.17 & $0.34 * *$ & $0.42 * * *$ & $0.37 * *$ & $0.31 * *$ & $0.33 * *$ & $0.65 * * *$ & $0.78 * * *$ & $0.70 * * *$ \\
\hline
\end{tabular}


Table 6. Averages of v17 overall exposure scores of the classified data for the older and side buildings $(n=37)$. The format of the results in the cells is average (minimum score-maximum score). Lower score refers to lesser exposure, i.e., better building.

\begin{tabular}{|c|c|c|c|c|c|c|c|}
\hline $\begin{array}{r}\text { Level of } \\
\text { maintenance } \\
\text { and } \\
\text { renovation }\end{array}$ & \multicolumn{2}{|c|}{ 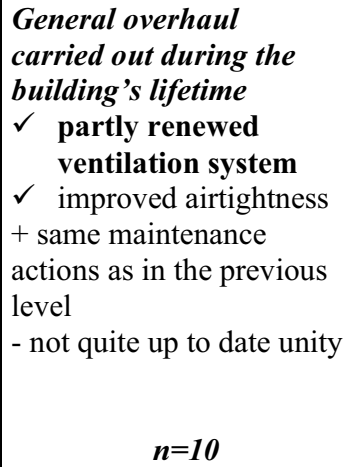 } & \multicolumn{2}{|c|}{$\begin{array}{l}\text { Major overhaul } \\
\text { carried out during the } \\
\text { building's lifetime } \\
\checkmark \quad \text { new balanced } \\
\text { ventilation, equivalent } \\
\text { in the whole building, } \\
\text { but not necessarily up } \\
\text { to date } \\
\text { + same maintenance and } \\
\text { renovation actions as in the } \\
\text { previous level } \\
\qquad n=12 \\
\end{array}$} & \multicolumn{2}{|c|}{ 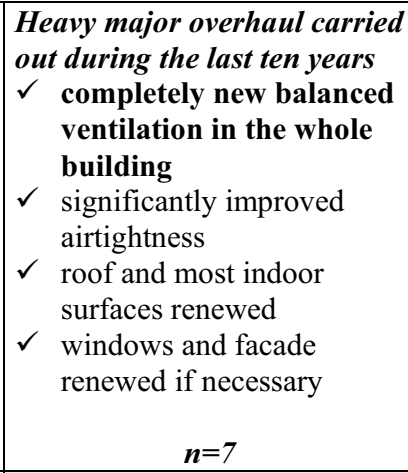 } & $\begin{array}{l}\text { Very heavy major } \\
\text { overhaul with renewed } \\
\text { façade } \\
n=3\end{array}$ \\
\hline $\begin{array}{c}\text { before } 1940 \\
n=7\end{array}$ & $\begin{array}{c}12,3(10-15) \\
n=3\end{array}$ & \multirow{3}{*}{$\begin{array}{c}12,1 \\
(9-15)\end{array}$} & $\begin{array}{c}10,8(7-13) \\
n=4\end{array}$ & \multirow{3}{*}{$\begin{array}{c}10,9 \\
(7-13)\end{array}$} & \multicolumn{2}{|c|}{$n=0$} & \\
\hline $\begin{array}{c}1941-1962 \\
n=11\end{array}$ & $\begin{array}{c}12,5(12-13) \\
n=4\end{array}$ & & \begin{tabular}{|c|}
$11,3(10-13)$ \\
$n=4$
\end{tabular} & & $\begin{array}{c}9,7(8-13) \\
n=3\end{array}$ & \multirow{2}{*}{$9,3(7-13)$} & \\
\hline $\begin{array}{c}1963-1980 \\
n=14 \\
\end{array}$ & $\begin{array}{c}11,3(9-15) \\
n=3\end{array}$ & & $\begin{array}{c}10,8(9-13) \\
n=4\end{array}$ & & $\begin{array}{c}9,0(7-11) \\
n=4 \\
\end{array}$ & & $\begin{array}{c}\text { average } 6,3 \\
(\min 5, \max 8) \\
\end{array}$ \\
\hline $\begin{array}{l}\text { side buildings } \\
\qquad n=5\end{array}$ & \multicolumn{7}{|c|}{ average $12,4(\min 11, \max 14)$} \\
\hline
\end{tabular}

Results of the overall exposure scores v17 for the newer buildings of the data are presented in Table 7. Averages in each category are so close to each other that the total average for all newer buildings in the data is illustrated in the last row of the table.

Table 7. Averages of v17 for the newer buildings $(n=16)$.

\begin{tabular}{|c|c|c|}
\hline & Original & Partly renovated \\
\hline $\begin{array}{c}1981-2000 \\
n=7\end{array}$ & $\begin{array}{c}10,2(8-14) \\
n=5\end{array}$ & $\begin{array}{c}10,5(9 \text { and } 12) \\
n=2\end{array}$ \\
\hline $\begin{array}{c}1998-2014 \\
n=9\end{array}$ & $10,2(8-14)$ & $n=0$ \\
\hline $\begin{array}{c}\text { all primary } \\
\text { buildings after } \\
1981, \boldsymbol{n}=\mathbf{1 6}\end{array}$ & \multicolumn{2}{|c|}{$10,3(8-14)$} \\
\hline
\end{tabular}

The total average for the complete data $(\mathrm{n}=53)$ with the side buildings included is 10,6 , the median is 11 , and the mode is 9 . Every category except buildings with very heavy major overhaul includes buildings with a higher exposure score than the average and median of the data. Average for all buildings with heavy major overhaul is not illustrated in Table 6, but it is 8,4 with a minimum of 5 and a maximum of $13(n=10)$.

Figure 3 shows the overall exposure scores v17 sorted by the years of construction. The trend line for the scores is slightly descending, but the figure illustrates that the variance is very high in every age group. Middle marks in the columns present the value of $2 * \mathrm{v} 15$, and the upper part of the column illustrates the value of v16. Scale for the overall exposure score estimate v17 was from 1 to 20 , but as we can see from the tables and Figure 3, the best buildings still scored grading 5 and the worst buildings only 15 .



Fig. 3. Overall exposure scores (v17) of the buildings and averages of v17 of certain eras of building. The side buildings are illustrated with darker columns without black border. Medians in the age groups are 12, 10 and 10. 


\section{Discussion and conclusions}

The main aim of the present study was to classify the buildings of the data for the later comparison between pupil reported symptoms. Methods and measures of the inspection were not very precise, and the scales for the variables are rough and partly subjective. Still, it should be noted that earlier studies on symptoms have often been done with the far less precise evaluation of buildings. Every building in this study went through a comprehensive assessment and was visited exclusively for the research. In some studies, it may not be described at all, how the allocation to damage and control buildings are made. The results of this study show that it is not possible to draw a clear line between the buildings with 'good' or 'poor' IEQ and suggest that allocating to only two categories can cause major errors.

In Finland, Senate Properties (work environment partner and specialist of the Finnish government) has developed a method to inspect all their buildings with a uniform comprehensive manner. Municipalities own more than four thousand school buildings, and they would benefit from a similar method [1]. These rough ratings could not be used for making decisions about the urgency of renovations. However, there is a need for a such tool and method, which would help municipalities to prioritize the renovations or closer investigations of their buildings. These variables and methods of inspection could be utilized for developing the tool.

The results cannot be generalized even though the building data is relatively large, and the age distribution of the data represents quite well the educational building stock of the whole Helsinki. Making nationwide generalizations about the condition of the school buildings would, of course, need larger data and locations from different municipalities of Finland. However, these results are indicative and suggests, as assumed, that the level of renovation results in better condition of the buildings. In fact, these results indicate that the buildings with the need for major overhaul should be renovated in a very heavy manner.

Many other aspects, such as intended service life, cost comparison between renovation methods (and new building), the functionality of spaces, and building preservation, affect the selection of the method for renovation. These results suggest that technically it is possible to renovate buildings of all ages to good condition. Of course, the renovation method is always a case-specific decision, and it should be clear that the health of the users should never be compromised or forgotten in the making of decisions.

Indoor air problems are common, and there are many factors to the risk of perceived health symptoms. Level of problems differ, but risks can be found in almost every building and some of those affect the whole building and some just locally in one spot or part of the structures, which may not have any connection to indoor air. Every building is unique, but the condition of buildings can be compared. The scale for comparison needs to be wide enough and take into account various aspects of possible problems in the buildings.
Studies about the condition of buildings are often done with the building data that includes only buildings with problems. This research studies all the possible school buildings of certain areas together with all Swedish-speaking schools in Helsinki, regardless of the building condition or complaints in the building.

Results of the present study are rather expected, but in this data, the newer buildings ended up with surprisingly high estimated exposure potentials, when estimated with the subjective and rough scale. Due to the lack of more comprehensive investigations in new buildings, we do not have a detailed understanding of the condition of the newer buildings. All buildings in the data are more than five years old, which prevents the possibility of comparing the condition between brand new buildings and newly renovated buildings. Nevertheless, the older buildings showed a slightly worse average, and it is clear that the damage in buildings always gets worse by the time if the maintenance is not sufficient.

Estimated exposures varied between buildings of every age category, and further analyses will show how well this estimated exposure correlates with the reported symptoms. In this study, we constructed separate overview variables and found at least moderate correlations between them.

Due to the relatively low number of positive findings for several single variables, it may not be likely to find an association between several of the single variables and pupil reported symptoms. For example, due to lack of variability, the relation between reported symptoms and emissions from the flooring cannot be studied in the later analyses of the research. Therefore, the summary scores will be of greatest interest in the analyses with perceived indoor air quality and symptoms.

The acknowledgements for the data are addressed to the city of Helsinki and especially to Kari Vähämäki for all the help. Funding for the research is from the Finnish Ministry of Social Affairs and Health and Tampere University's faculty of Build Environment. Special thanks to Kateryna Savelieva for running the correlations between the variables.

\section{References}

1. E. Korhonen, J. Niemi, R. Ekuri, R. Oksanen, H. Miettinen, J. Parviainen, A. Haapanen, T. Patanen. Publications of the Government's analysis, assessment and research activities 5, (2018) (in Finnish)

2. T. Marttila, P. Annila, P. Kero, J. Suonketo. Building Pathology and Rehabilitation (Springer book). Case Studies of Building Pathology in Cultural Heritage, 7, 115-131 (2016)

3. K. Tähtinen, S. Lappalainen, K. Karvala, J. Remes, H. Salonen. Int. J. Environ. Res. Public Health, 15, 679 (2018)

4. K. Tähtinen, S. Lappalainen, K. Karvala, M. Lahtinen, H. Salonen. Appl. Sci., 9, 99 (2018)

5. K. Savelieva, T. Marttila, J. Lampi, S. Ung-Lanki, M. Elovainio, J. Pekkanen. Environmental Health, 18:115, 12 (2019) 